\title{
THE ACUTE ORAL TOXICITY OF COMMONLY USED PESTICIDES IN IRAN, TO HONEYBEES (APIS MELLIFERA MEDA)
}

\author{
Farhang Rasuli \\ Javad Nazemi Rafie* \\ Amin Sadeghi \\ University of Kurdistan, Faculty of Agriculture, \\ Plant Protection Department, 6617715175 Sanadaj, Kurdistan Province, Iran \\ *corresponding author: j.nazemi@uok.ac.ir \\ Received 10 June 2014, accepted 14 February 2015
}

\begin{abstract}
A b s t r a t
The honey bee is credited with approximately $85 \%$ of the pollinating activity necessary to supply about one-third of the world's food supply. Well over 50 major crops depend on these insects for pollination. The crops produce more abundantly when honey bees are plentiful. Worker bees are the ones primarily affected by pesticides. Poisoning symptoms can vary depending on the developmental stage of the individual bee, and the kind of chemical employed. The oral toxicity of these insecticides: (phosalone and pirimicarb), acaricide (propargite), insecticide and acaricide (fenpropathrin), fungicides, and bactericides (copper oxychloride and the Bordeaux mixture), were evaluated for the purposes of this research. The results showed that fenpropathrin had high acute oral toxicity $\left(\mathrm{LC}_{50}-24 \mathrm{~h}\right.$ and $\mathrm{LC}_{50}-48$ were 0.54 and $0.3 \mathrm{ppm}$, respectively). Propargite had $7785 \mathrm{ppm}$ (active ingredient) for $\mathrm{LC}_{50}-24 \mathrm{~h}$ and $6736 \mathrm{ppm}$ (active ingredient) for $\mathrm{LC}_{50}-48 \mathrm{~h}$ in honeybees and is therefore, non-toxic to Apis mellifera. On the other hand, copper oxychloride had minimum acute oral toxicity to honeybees $\left(\mathrm{LC}_{50}-24 \mathrm{~h}\right.$ and $\mathrm{LC}_{50}-48$ were 4591.5 and $\mathbf{5 4 0 7 . 9} \mathrm{ppm}$, respectively) and was therefore considered non-toxic. Also, the Bordeaux mixture was safe to use around honeybees. Phosalone and primicarb were considered highly and moderately toxic to honeybees, respectively.
\end{abstract}

Keywords: acute oral toxicity, Apis mellifera meda, $\mathrm{LC}_{50}$, pesticide.

\section{INTRODUCTION}

The honeybee Apis mellifera is valuable for the economy due to its hive by-products (honey, pollen, royal jelly) which generate considerable income for beekeepers. Honeybees also contribute to plant biodiversity by pollinating wild plants. Honeybees and their products are potentially exposed to several contaminants present in the environment, such as chemical products released into the hive to fight diseases and parasites, and pesticides used in agriculture against pests (Aliouane et al., 2009). As a response, multiple studies were conducted to assess pesticide residues in the field. The results were dramatic. For example, a study of apiaries in North American orchards recovered 121 agrochemicals in honeybees, pollen, and the wax (Mullin et al., 2010). However, the impact of the agricultural landscape is not limited to honeybee colonies. In fact, other pollinators also suffer. In the last
40 years, non-Apis species, such as bumblebees, are decreasing in great quantities (Goulson et al., 2008). Honeybees are estimated to provide annual pollination services worth US $\$ 4.1$ billion to agriculture. Every year tens of beekeepers with hundreds of bee colonies move to various hills and valleys of Himachal Pradesh to provide pollination services to apple farmers. In return, the beekeepers get paid for their services. Farmers pay beekeepers IRs 800 (US \$18) as a pollination fee for one colony of honeybees during each flowering season (Hepburn and Radloff, 2011).

Chemicals may elicit various effects in biological organisms through their interaction with numerous molecular targets that can induce lethal and adverse sublethal effects (Sattelle and Yamamoto, 1988; Soderlund and Bloomquist, 1989). This can be exemplified by the neurotoxic pyrethroid, carbamate, and organophosphate pesticides which can trigger not only more of less severe neural effects but also reprotoxicity through a mechanism independent of 
their neural action (Yousef, 2010; Zhang et al., 2010; Joshi et al., 2011). Previous studies have shown that low-dosage deltamethrin will delay the return time (Vandame et al., 1995) and reduce foraging activity (Decourtye et al., 2004). In addition, cypermethrin leads to the extinction of bees (Bendahou and Bounias, 1999) while parathion influences communication between bees (Schricker and Stephen, 1970). Direct spray plays a significant role in the contamination of flower nectar. Nectar and other sugar sources (e.g. extra floral nectaries and aphid honey dew) are used as an energy source. Spray applications at or close to the flowering period, pose the greatest likelihood of acute exposure for bees. This can cause direct contamination of flower nectar (Alex and Miles, 2011). Nectar sugar is most important for attracting honeybees. The direct effects of nectar sugar concentration were positive and negligible (Hepburn and Radloff, 2011).

In the assessment and evaluation of toxic characteristics of substances, it may be required to determine the acute oral toxicity in honeybees, e.g. when it is likely that bees will be exposed to a given chemical. The acute oral toxicity test is carried out to determine the inherent toxicity of pesticides and other chemicals to honeybees. Simulation of flower nectar and aphid honeydew is done by mixing pesticides with a sucrose solution. In particular, this method can be used in step-wise programs for evaluating the hazards of pesticides to bees, based on sequential progression from laboratory toxicity tests to semi-field and field experiments (EPPO/ Council of Europe, 1993; OECD, 1998; Laurino et al., 2010; 2011; 2013). Therefore, both active substances (a.s.) and formulated pesticides are currently undergoing various tests. The tests assess the risk posed by a.s. and formulated pesticides to honey bees, before the a.s. and pesticides are allowed to be used in agriculture. In the European Union, the European and Mediterranean Plant Protection Organization guidelines No. 170 (OEPP/ EPPO, 2010a) and the relative risk assessment scheme (OEPP/EPPO, 2010b) are usually followed. Such procedures substantially rely on Median Lethal Dose $\left(\mathrm{LD}_{50}\right)$ or another similar toxicity index-determination to ascertain if risk levels associated with the tested a.s. are acceptable for honey bees.

To test the toxicity of insecticides, animal experiments are used to estimate the half-lethal dosage $\left(L_{50}\right)$ or lethal concentration $\left(L C_{50}\right)$, and thus, estimate the possible harm to humans and non-target organisms. For non-target organisms, insecticides not only can cause direct poisoning or death of bees, it can also influence the bee larvae, division of labor, foraging as well as the development of bee colonies while subjecting all of the above to a lower lethal dose (Thompson, 2003).

Since there is no published information on the precise acute oral toxicity $\left(\mathrm{LC}_{50}\right)$ of the six pesticides: fenpropathrin, pirimicarb, propargite, phosalone, copper oxychloride, and Bordeaux mixture on Apis mellifera meda, evaluations of $\mathrm{LC}_{50}-24 \mathrm{~h}$, and $\mathrm{LC}_{50}-48 \mathrm{~h}$ were conducted to address this lack. The aims of this study were the calculation of $L_{50}-24 h$, and $L C_{50}-48 \mathrm{~h}$ of the aforementioned six commonly used pesticides, and the significant evaluation between $\mathrm{LC}_{50}-24 \mathrm{~h}$ and $\mathrm{LC}_{50}-48 \mathrm{~h}$ in Iran.

\section{MATERIAL AND METHODS}

Commonly used formulations available in Iran were implemented in the study. The formulations contained: fenpropathrin (Danitol ${ }^{\oplus}, 10 \%$ Emulsion), pirimicarb (Pirimor ${ }^{\oplus}, 50 \%$ wetable), propargite (Omite ${ }^{\oplus}, \mathrm{D}-014^{\oplus}, \mathrm{BPPS}^{\oplus}{ }^{\circ}$ Comite $^{\oplus}, 57 \%$ Emulsion), phosalone (Zolone ${ }^{\oplus} 35.0 \%$ Emulsion), copper oxychloride (Cupravite, 355 ${ }^{\circ}, 35 \%$ wetable), and Bordeaux mixture (Bordeaux Fix ${ }^{\oplus}, 18 \%$ Emulsion). Forager adult worker bees of the same species were used for oral toxicity. Honeybees were obtained from adequately fed, healthy, disease-free, and queen-right colonies. Treated honeybees were held in plastic cages. The cages were $30 \mathrm{~cm}$ high and $20 \mathrm{~cm}$ wide. Mesh-like nets for ventilation were used in parts of the cage. A sleeve-like net was used to transfer the treatment petri dish into the cage (Fig. 1). Treatment doses were mixed with a sucrose solution in water $(25 \% \mathrm{w} / \mathrm{v})$. The honeybees were starved for up to 2 hours before the initiation of the test. Lethal experiments were conducted using 315 honeybee adults for each pesticide and there was also a control. Three cages (the repetitions) were used in each treatment and the control. In each cage, 15 worker honeybees were placed. Worker honeybees under anesthesia, were mechanically transferred to each cage. A pretest experiment was conducted then six concentrations and the control were designed using the six pesticides. After a 1 hour treatment, all honeybees were fed with a non-toxic sucrose solution in water $(50 \% \mathrm{w} / \mathrm{v})$. The mortality rates were logged at 24,48 , and $72 \mathrm{~h}$ after the start of the test. The tests were performed in a dark room at $25-30^{\circ} \mathrm{C} ; 45-55 \%$ relative humidity (Laurino et al., 2010; 2011; 2013). The pretest experiments were conducted for designing the concentrations. Concentrations causing $10 \%$ and $90 \%$ mortality 


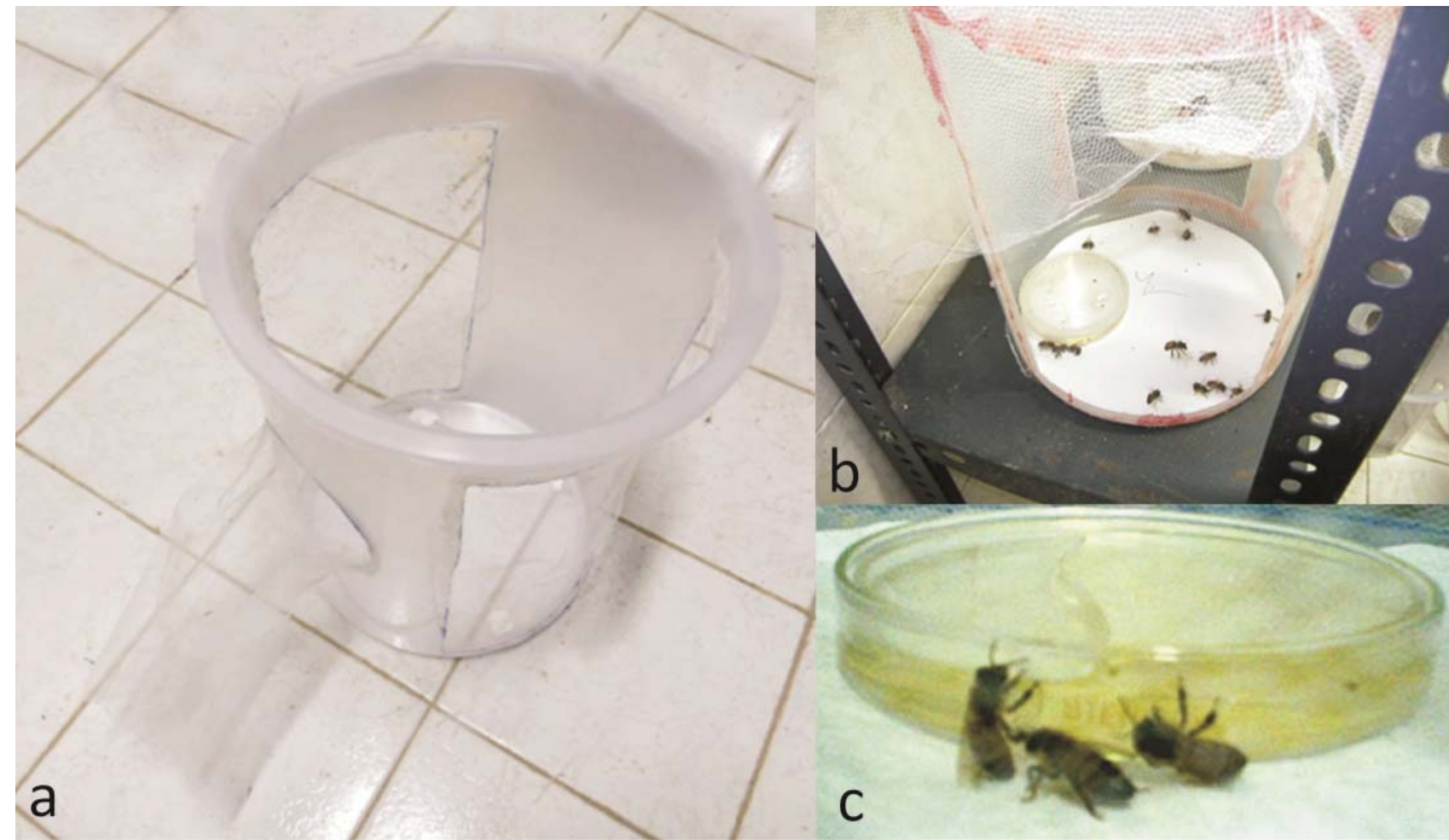

Fig. 1. Cage with a sleeve-like net was used to transfer the treatment petri dish into the cage (a);

Cage prepared for the ingestion trials with treatment doses mixed with a sucrose solution

$(25 \% \mathrm{w} / \mathrm{v})$ in water (b); detail of the feeder pointing out the narrow space where the bees could feed (c).

were obtained, then concentrations between them were designed. The experiments were prolonged until the time (day) that the control mortality did not exceed 10 percent ( $\leq 10 \%)$ (OECD, 1998; Laurino et al., 2013). In our experiment, the control mortality exceeded 10 percent after 72 hours $(\geq 10 \%)$, therefore we did not continue our observation records to 96 hours. Our acute oral toxicity experiment continued up to 72 hours. Polo-PC software was used to do the calculation of the potential toxicity presented as $\mathrm{LC}_{50}-24 \mathrm{~h}, \mathrm{LC}_{50}-48 \mathrm{~h}$, $\mathrm{LC}_{50}-72 \mathrm{~h}$. Probit regressions were plotted by SPSS ver. 18. A significant comparison between $\mathrm{LC}_{50}-24 \mathrm{~h}$ and $\mathrm{LC}_{50}-48 \mathrm{~h}$ was conducted with the lethal dose ratio method (Robertson and Preisler, 1992). Concentrations used for determining the $\mathrm{LC}_{50}$ were: fenpropathrin- 0.1, 0.3, 0.5, 0.6, 0.8, and 1 ppm (active ingredient); primicarb- 50, 90, 150, 300, 400, and 480 (active ingredient); phosalone- 10, 50, 100, 200, 300, and 400 ppm (active ingredient); propargite5000, 6000, 7000, 8000, 9000, and 10000 (active ingredient); Bordeaux mixture - 2500, 3300, 4200, 5000, 6000, and 6800 (active ingredient); copper oxychloride- 3500, 4000, 4800, 5600, 6500, and 7000 ppm (active ingredient).

\section{RESULTS}

In our experiment, the control mortality exceeded 10 percent after 72 hours ( $\geq 10 \%)$, therefore we did not continue our observation records to 96 hours. Our experiment continued to up to 72 hours. The results of the fenpropathrin concentrations indicated that the concentration of $0.8 \mathrm{ppm}$ caused mortalities of $82.2,95.5$, and $97.7 \%$ at $24 \mathrm{~h}, 48 \mathrm{~h}$, and $72 \mathrm{~h}$, respectively. Fenpropathrin had the highest toxicity rate when compared to the other pesticides (Fig. 3a). The results showed that for fenpropathrin, $\mathrm{LC}_{50}-24 \mathrm{~h}$ was $0.54 \mathrm{ppm}$, whereas $\mathrm{LC}_{50}-48 \mathrm{~h}$ and $\mathrm{LC}_{50}-72 \mathrm{~h}$ were 0.3 and 0.28 ppm, respectively (Tab. 1). There were correlations of $0.97,0.99$, and 0.98 between the logarithm of concentrations and mortality probit at $24 \mathrm{~h}, 48 \mathrm{~h}$, and $72 \mathrm{~h}$, respectively (Fig. 2). There was a significant difference between $\mathrm{LC}_{50}-24 \mathrm{~h}$ and $\mathrm{LC}_{50}-48 \mathrm{~h}$ (lethal dose ratio $=1.5-2.2$ ). There was no significant difference between $\mathrm{LC}_{50}-48 \mathrm{~h}$ and $\mathrm{LC}_{50}-72 \mathrm{~h}$ (lethal dose ratio $\left.=0.8-1.3\right)($ Tab. 2). There was a significant difference between $\mathrm{LC}_{50}-24 \mathrm{~h}$ and $\mathrm{LC}_{50}-48 \mathrm{~h}$ (lethal dose ratio $\left.=1.2-1.8\right)($ Tab. 2). The results of primicarb concentrations indicated that a concentration of $400 \mathrm{ppm}$ caused mortalities of $77.7,93.3$, and $97.7 \%$ at $24 \mathrm{~h}, 48 \mathrm{~h}$, and $72 \mathrm{~h}$, respectively (Fig. $3 \mathrm{~b}$ ). The results indicated that the 

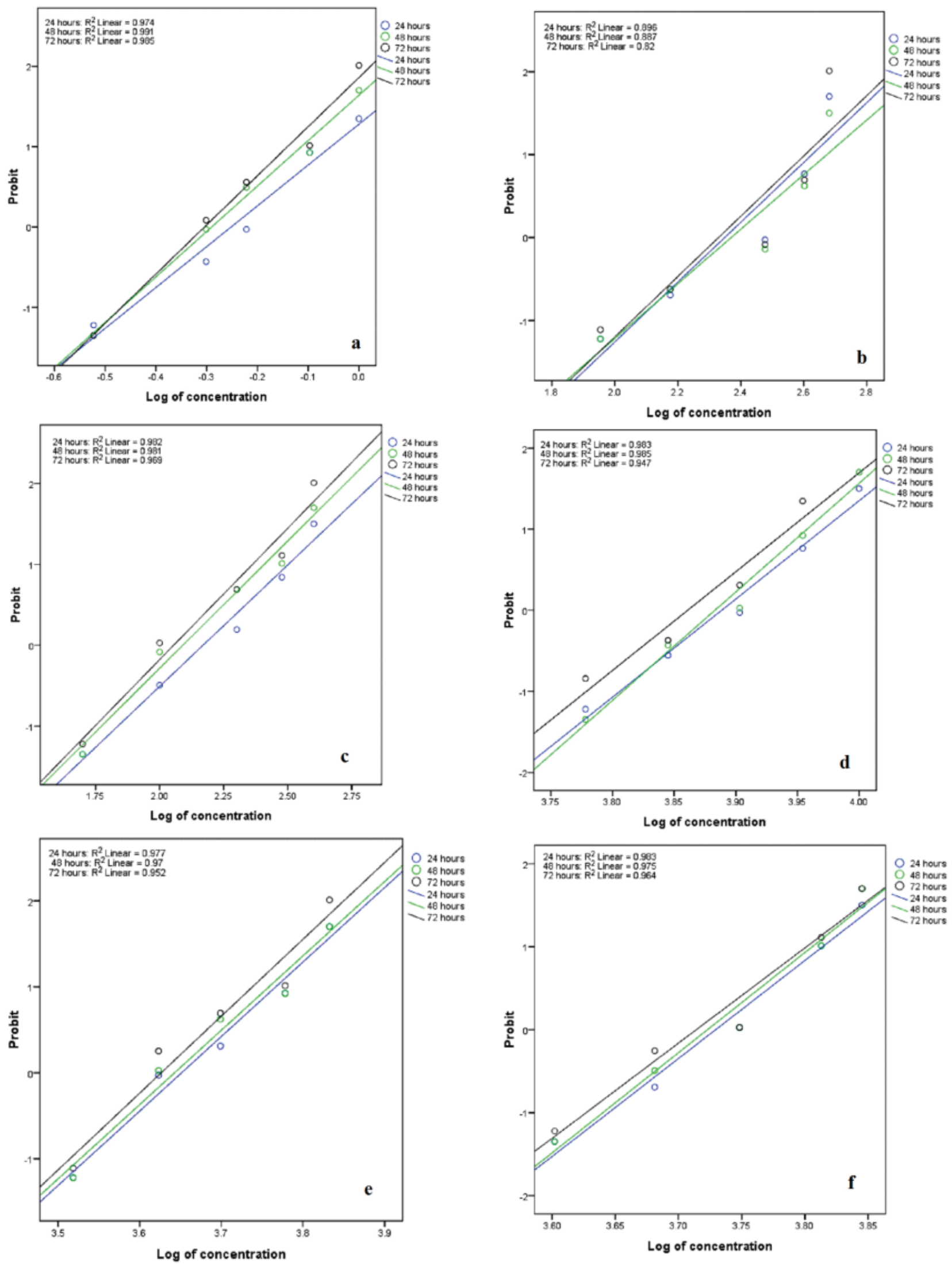

Fig. 2. Probit regression lines of pesticides commonly used in Iran, in 24h and 48h; a - fenpropathrin, b -primicarb, $c$ - phosalone, $d$ - propargite, e - Bordeaux mixture, $f$ - copper oxychloride. 

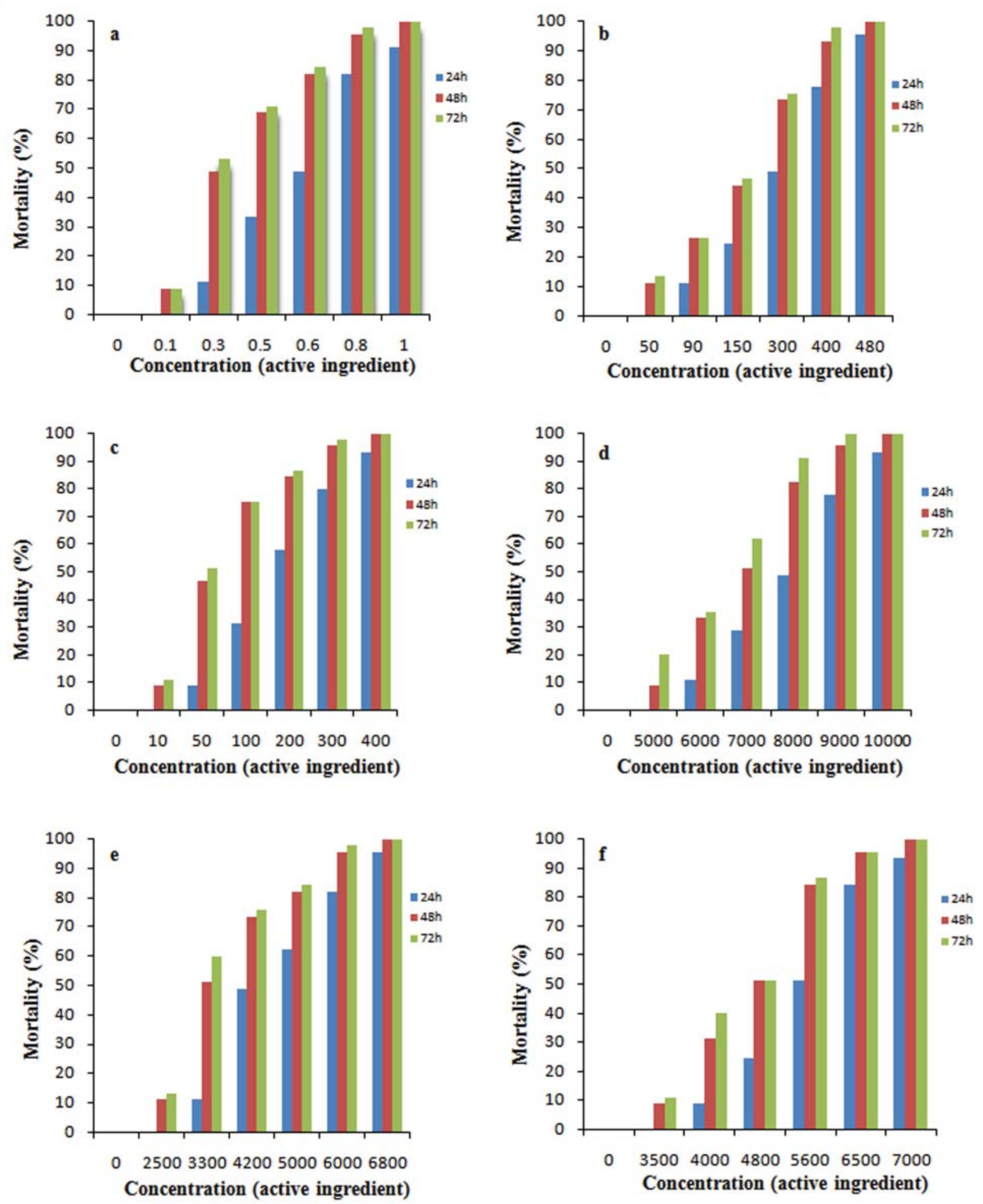

Fig. 3. Mortality comparisons of honeybee adults when different concentrations of: a - fenpropathrin, b -primicarb, c - phosalone, d - propargite, e - Bordeaux mixture, f - copper oxychloride were used at 24h, 48h, and 72h. 
$\mathrm{LC}_{50}-24 \mathrm{~h}$ of Pirimicarb was 220.8ppm. Also, the $\mathrm{LC}_{50}-48 \mathrm{~h}$ and $\mathrm{LC}_{50}-72 \mathrm{~h}$ were 153.7 and $143.4 \mathrm{ppm}$, respectively (Tab. 1). Furthermore, there were correlations of $0.89,0.88$, and 0.82 between the logarithm of concentrations and mortality probit at $24 \mathrm{~h}, 48 \mathrm{~h}$, and $72 \mathrm{~h}$, respectively (Fig. 2). There was a significant difference between the $\mathrm{LC}_{50}-24 \mathrm{~h}$ and $\mathrm{LC}_{50}-48 \mathrm{~h}$ (lethal dose ratio $=1.2-1.8)$. Also, There was no significant difference between the $\mathrm{LC}_{50}-48 \mathrm{~h}$ and $L_{50}-72 \mathrm{~h}$ (lethal dose ratio $=0.8-1.3$ ) (Tab. 2).

The phosalone concentration of $300 \mathrm{ppm}$ had mortalities of $80,95.5$, and $97.7 \%$ at $24 \mathrm{~h}, 48 \mathrm{~h}$, and $72 \mathrm{~h}$, respectively (Fig. $3 c$ ). In our study, the $L_{50}-24 h$, $\mathrm{LC}_{50}-48 \mathrm{~h}$, and $\mathrm{LC}_{50}-72 \mathrm{~h}$ of phosalone were 151.1, 55.8 and $48.2 \mathrm{ppm}$, respectively. There was a significant difference between the mortalities of the applied concentrations at $24 \mathrm{~h}(\mathrm{~F}=134.88$, $P=0.00)$. Probit regression was plotted at $24 \mathrm{~h}$ and 48h. The results illustrated the correlations of $0.98,0.98$, and 0.96 between the logarithm of the concentrations and mortality probit at $24 \mathrm{~h}, 48 \mathrm{~h}$, and $72 \mathrm{~h}$, respectively (Fig. 2). There was a significant difference between the $\mathrm{LC}_{50}-24 \mathrm{~h}$ and $\mathrm{LC}_{50}-48 \mathrm{~h}$ (lethal dose ratio $=2.02-3.8$ ). Additionally, there was no significant difference between the $\mathrm{LC}_{50}-48 \mathrm{~h}$ and $\mathrm{LC}_{50}-72 \mathrm{~h}$ (lethal dose ratio $=0.73-1.6$ ) (Tab. 2).

A propargite concentration of $9000 \mathrm{ppm}$ caused mortalities of $77.7,95.5$ and $100 \%$ at $24 \mathrm{~h}, 48 \mathrm{~h}$, and 72h, respectively (Fig. 3d). In our study, the $\mathrm{LC}_{50}-24 \mathrm{~h}$ for propargite was 7785 ppm but this was reduced to 6736 and $6349.9 \mathrm{ppm}$ at $\mathrm{LC}_{50}-48 \mathrm{~h}$ and $\mathrm{LC}_{50}-72 \mathrm{~h}$, respectively (Tab. 1). There was a significant difference between the mortalities of the applied concentrations at $24 \mathrm{~h}(\mathrm{~F}=116.15, \mathrm{P}=0.00)$. There was a significant difference between the $\mathrm{LC}_{50}-24 \mathrm{~h}$ and $\mathrm{LC}_{50}-48 \mathrm{~h}$ (lethal dose ratio $=1.09-1.22$ ). There was no significant difference between the $\mathrm{LC}_{50}-48 \mathrm{~h}$ and $\mathrm{LC}_{50}-72 \mathrm{~h}$ (lethal dose ratio $\left.=0.9-1.1\right)($ Tab. 2). Correlations between the logarithm of the concentrations and mortality probit were $0.98,0.98$, and 0.94 for $24 \mathrm{~h}, 48 \mathrm{~h}$, and $98 \mathrm{~h}$, respectively (Fig. 2).

The Bordeaux mixture concentration of $6000 \mathrm{ppm}$ caused mortalities of $82.2,95.5$, and $97.7 \%$ at $24 \mathrm{~h}$, $48 \mathrm{~h}$, and $72 \mathrm{~h}$, respectively (Fig. 3e). The $\mathrm{LC}_{50}-24 \mathrm{~h}$, $\mathrm{LC}_{50}-48 \mathrm{~h}$ and $\mathrm{LC}_{50}-72 \mathrm{~h}$ of the Bordeaux mixture were correspondingly 4469, 3519, and 3363.4 ppm (Tab. 1). The results indicated that at $24 \mathrm{~h}, 48 \mathrm{~h}$, and $72 \mathrm{~h}$, there were correlations of $0.97,0.97$, and 0.95 between the logarithm of the concentrations and the mortality probit, respectively (Fig. 2). There was a significant difference between $\mathrm{LC}_{50}-24 \mathrm{~h}$ and $\mathrm{LC}_{50}-48 \mathrm{~h}$ (lethal dose ratio $=1.1-1.3$ ). Also, there

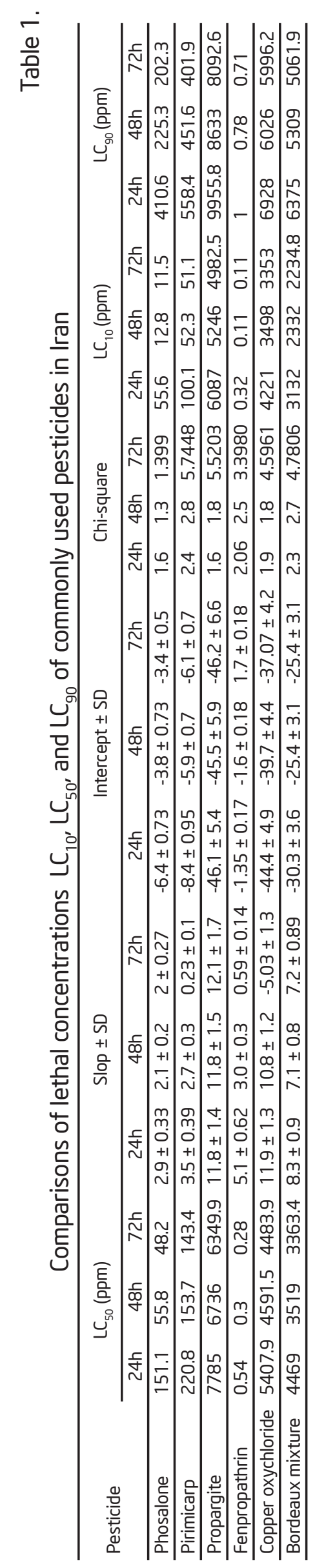


Table 2.

Significant evaluation and parallelism hypothesis between lethal concentrations $\mathrm{LC}_{50}-24$ hours and $\mathrm{LC}_{50}-72$ hours with $\mathrm{LC}_{50}-48$ hours of pesticides

\begin{tabular}{|c|c|c|c|c|c|c|c|c|}
\hline \multirow[b]{2}{*}{ Pesticide } & \multicolumn{3}{|c|}{$\mathrm{LC}_{50}$} & \multicolumn{2}{|c|}{ Parallelism (Chi-square) } & \multirow[t]{2}{*}{$d f$} & \multicolumn{2}{|c|}{$\begin{array}{l}\text { Lethal Dose Ratio } \\
\text { (lower-upper limits) }\end{array}$} \\
\hline & $\begin{array}{l}24 \\
\text { hours }\end{array}$ & $\begin{array}{l}48 \\
\text { hours }\end{array}$ & $\begin{array}{l}72 \\
\text { hours }\end{array}$ & $\begin{array}{l}24 \text { hours with } \\
48 \text { hours }\end{array}$ & $\begin{array}{l}72 \text { hours with } \\
48 \text { hours }\end{array}$ & & $\begin{array}{l}24 \text { hours } \\
\text { with } 48 \\
\text { hours }\end{array}$ & $\begin{array}{l}72 \text { hours } \\
\text { with } 48 \\
\text { hours }\end{array}$ \\
\hline Phosalone & 151.1 & 55.85 & 48.2 & $4.2^{*}(P<0.05)$ & $5.5(P>0.05)$ & 2 & $2-3.8^{\star \star}$ & $0.73-1.6$ \\
\hline Primicarp & 220.8 & 153.7 & 143.4 & $1.8(P>0.05)$ & $2.05(P>0.05)$ & 2 & $1.2-1.8$ & $0.8-1.3$ \\
\hline Propargite & 7785 & 6736 & 6349.9 & $0.01(P>0.05)$ & $9.1(P<0.05)$ & 2 & $1-1.2$ & $0.9-1.1$ \\
\hline Fenpropathrin & 0.54 & 0.3 & 0.28 & $8.6 *(P<0.05)$ & $9.7(P<0.05)$ & 2 & $1.5-2.2$ & $0.8-1.3$ \\
\hline Copper oxychloride & 5407.9 & 4591.5 & 4483.9 & $0.35(P>0.05)$ & $1.01(P>0.05)$ & 2 & $1.1-1.2$ & $0.96-1.09$ \\
\hline Bordeaux mixture & 4469 & 3519 & 3363.4 & $0.74(P>0.05)$ & $0.91(P>0.05)$ & 2 & $1.1-1.3$ & $0.94-1.1$ \\
\hline
\end{tabular}

was no significant difference between $\mathrm{LC}_{50}-48 \mathrm{~h}$ and $\mathrm{LC}_{50}-72 \mathrm{~h}$ (lethal dose ratio $\left.=0.94-1.1\right)($ Tab. 2). The copper oxychloride concentration of $6500 \mathrm{ppm}$ caused mortalities of $84.4,95.5$, and $95.5 \%$ at $24 \mathrm{~h}$, 48h, and 72h, respectively (Fig. 3f). As can be seen in Table 1, the $L C_{50}-24 \mathrm{~h}, L C_{50}-48 \mathrm{~h}$, and $\mathrm{LC}_{50}-72 \mathrm{~h}$ of copper oxychloride were 5407.9, 4591.5, and 4483.9 ppm, respectively. There was a significant difference between the mortalities of the applied concentrations at $24 \mathrm{~h}(\mathrm{~F}=136.15, \mathrm{P}=0.00)$. There was a significant difference between the $\mathrm{LC}_{50}-24 \mathrm{~h}$ and $\mathrm{LC}_{50}-48 \mathrm{~h}$ (lethal dose ratio $=1.1-1.2$ ). There was no significant difference between the $\mathrm{LC}_{50}-48 \mathrm{~h}$ and $\mathrm{LC}_{50}-72 \mathrm{~h}$ (lethal dose ratio $=0.96-1.09$ ) (Tab. 2). Probit regression was plotted at $24 \mathrm{~h}$ and $48 \mathrm{~h}$. The results showed that at $24 \mathrm{~h}, 48 \mathrm{~h}$, and $72 \mathrm{~h}$, there were correlations of $0.98,0.97$, and 0.96 between log concentrations and mortality probit, respectively (Fig. 2).

\section{DISCUSSION}

In our research, the risk assessments of the six studied pesticides have only been limited in some fragmented data. In the past, systemic compounds like neonicotinoids were recovered in pollen. Recently, large studies in Europe and North America showed the presence of pesticide residues in pollen collected by honeybees (Skerl et al., 2009; Mullin et al., 2010; Wu et al., 2011). Pesticides have been known to induce behavioral changes in adult bees (Thompson, 2003). To date, several studies have demonstrated that ingestion of small amounts of pesticides (e.g. imidacloprid, deltamethrin) by adult honeybees (Colin et al., 2001; Decourtye et al., 2003) interferes with the honeybees' learning and orientation capacity.
Our research showed that the $\mathrm{LC}_{50}-24 \mathrm{~h}$ and $\mathrm{LC}_{50}-48 \mathrm{~h}$ of phosalone were 151.1 and 55.8 ppm (active ingredient), respectively. Additionally, the $\mathrm{LC}_{90}-24 \mathrm{~h}$ was 410.6 ppm (active ingredient). In the usage instructions for the trade formulation of phosalone, $35 \%$ is from 0.525 to $0.91 \mathrm{~kg} / \mathrm{ha}$ active substance for controlling pests. Thus, this insecticide is highly toxic to honeybees. It was reported that the $L_{50}$ of phosalone was $89000 \mu \mathrm{g} / \mathrm{kg}$ on Apis mellifera (Thompson, 2012). Assessment of acute contact toxicity of phosalone on Megachile rotunda showed that the usage of $1 \mathrm{~kg} / \mathrm{ha}$ caused $95 \%$ mortality at 24h (Tasei et al., 1987). Oral toxicity of phosalone on Bombus terrestris was evaluated by Marletto et al. (2003). They found that the $L_{50}-24 \mathrm{~h}$ was 3.98 ppm. There is only fragmented data about moderately toxic phosalone used around honeybees (Mayer et al., 1999; Sanford, 2009; Adams and Bartholomew, 2012).

Pirimicarb is a carbamate compound that acts as a selective insecticide. The mode of action of carbamates is somewhat similar with organophosphate compounds. Our research showed that the $\mathrm{LC}_{50}-24 \mathrm{~h}$ and $\mathrm{LC}_{50}-48 \mathrm{~h}$ of pirimicarb were 220.8 and 153.7 ppm (active ingredient), respectively. Moreover, $\mathrm{LC}_{90}-24 \mathrm{~h}$ was 558.4 ppm (active ingredient). The usage instructions for the trade formulation of pirimicarb $50 \%$, is from 0.25 to $0.35 \mathrm{~kg} / \mathrm{ha}$ active substance for controlling pests. Therefore, this insecticide is moderately toxic to honeybees. Using $0.28 \mathrm{~kg}$ of the active ingredient per hectare caused an $8 \%$ mortality in honeybees. The median lethal dose $\left(\mathrm{LD}_{50}\right)$ of acute contact toxicity and oral toxicity were $54 \mu \mathrm{g} / \mathrm{bee}$ and $3.2 \mu \mathrm{g} / \mathrm{bee}$, respectively (Stevenson, 1978). It has been reported that $L_{50}$ of phosalone was $89000 \mu \mathrm{g} / \mathrm{kg}$ on Apis mellifera (Thompson, 2012). 
Propargite $57 \%$ is an acaricide that uses from $0.57 \mathrm{~kg}$ to $0.85 \mathrm{~kg} / \mathrm{ha}$ of active substance for control of mites in Iran. This acaricide had 7785 ppm (active ingredient) for the $\mathrm{LC}_{50}-24 \mathrm{~h}$ and $6736 \mathrm{ppm}$ (active ingredient) for the $\mathrm{LC}_{50}-48 \mathrm{~h}$ in honeybees and, therefore, is non-toxic to Apis mellifera. Fenpropathrin had the highest toxicity compared to the other pesticides $\left(\mathrm{LC}_{50}-24 \mathrm{~h}\right.$ and $\mathrm{LC}_{50}-48 \mathrm{~h}, 0.54$ and $0.3 \mathrm{ppm}$ (active ingredient), respectively). Some researchers have reported that farmers should not use fenpropathrin when fruit trees are blossoming (Mayer et al., 1999; Riedl et al., 2006).

There is no precise information about acute contact toxicity in fungicides and bactericides of copper oxychloride, and the Bordeaux mixture. Usage of the Bordeaux mixture is; $1.8 \mathrm{~kg} / \mathrm{ha}$ active substance. Also, from 0.35 to $1 \mathrm{~kg} / \mathrm{ha}$ of the active substance of copper oxychloride is used in Iran. Our research showed that the $\mathrm{LC}_{50}-24 \mathrm{~h}$ of copper oxychloride, and the $\mathrm{LC}_{50}-24 \mathrm{~h}$ of the Bordeaux mixture were 5407.9 and 4469 (active ingredient), respectively. Therefore, these pesticides were considered non-toxic to honeybees. Tesoriero et al. (2003) showed that $1 \mu \mathrm{L}$ copper oxychloride did not have a toxic effect on adult Osmia cornuta (Latreille), but this pesticide (1 $\mu$ L/egg) did cause $40 \%$ mortality in eggs.

\section{CONCLUSIONS}

Risk assessments of the six pesticides showed that phosalone (insecticide) and fenpropathrin (acaricide and insecticide) are highly toxic to honeybees and they must not be used when honeybees are foraging. Additionally, propargite (acaricide), copper oxychloride, and the Bordeaux mixture (fungicides and bactericides) are non-toxic when used around honeybees. Therefore, propargite (acaricide), copper oxychloride, and the Bordeaux mixture (fungicides and bactericides) can be used safely when honeybees are foraging (Apis mellifera).

\section{ACKNOWLEDGMENTS}

The authors would like to thank the Plant Protection Department, Faculty of Agriculture, University of Kurdistan, Iran, for their financial assistance.

\section{REFERENCES}

Adams R. G., Bartholomew C. (2012) Protecting honey bees from pesticide poisoning. University of Connecticut. 7 pp.

Alex A., Miles M. (2011) Exposure of honey bees and other pollinating species to pesticides. $11^{\text {th }}$ International Symposium of the ICP-BR Bee Protection Group. Wageningen (The Netherlands), November 2-4: 19-29. DOl: 10.5073/jka.2012.437.006

Aliouane Y., Hassani A., Gary V., Armengaud C., Lambin M., Gauthier M. (2009) Subchronic exposure of honeybees to sublethal doses of pesticides: effects on behavior. Environmental Toxicology and Chemistry 28(1): 113-122.

Bendahou N., Bounias M. (1999) Biological and biochemical effects of chronic exposure to very low levels of dietary cypermethrin (Cymbush) on honeybee colonies (Hymenoptera: Apidae). Ecotoxicology and Environmental Safety 44: 147-153.

Colin M. E., Le Conte Y., Vermandere J. P. (2001) Managing nuclei in insect-proof tunnel as an observation tool for foraging bees. In: Belzunces L. P., Pélissier C., Lewis G. B. (Eds.) Hazards of Pesticides to Bees. Sublethal effects of deltamethrin and imidacloprid. INRA. Paris: 259-268.

Decourtye A., Lacassie E., Pham-Delègue M. H. (2003) Learning performances of honeybees (Apis mellifera L.) are differentially affected by imidacloprid according to the season. Pest Management Science 59(3): 269-278.

Decourtye A., Devillers J., Cluzeau S., Charreton M., PhamDelègue M. H. (2004) Effects of imidacloprid and deltamethrin on associative learning in honeybees under semi-field and laboratory conditions. Ecotoxicology and Environmental Safety 57: 410-419.

EPPO/Council of Europe (1993) Decision-Making Scheme for the Environmental Risk Assessment of Plant Protection Products - Honeybees. EPPO bulletin 23(1): 151 165.

Goulson D., Lye G. C., Darvill B. (2008) Decline and conservation of bumble bees. Annual Review of Entomology 53: 191-208.

Hepburn R., Radloff S. (201 1) Honeybees of Asia. Springer-Verlag. Berlin Heidelberg. 683 pp. 
Joshi S. C., Bansal B., Jasuja N. D. (201 1) Evaluation of reproductive and developmental toxicity of cypermethrin in male albino rats. Environmental Toxicology and Chemistry 93: 593-602.

Laurino D., Manino A., Patetta A., Ansaldi M., Porporato M. (2010) Acute oral toxicity of neonicotinoids on different bee strains. Redia 93: 99-102.

Laurino D., Manino A., Patetta A., Ansaldi M., Porporato M. (2011) Toxicity of neonicotinoid insecticides to honey bees: laboratory tests. Bulletin of Insectology 64: 107113.

Laurino D., Manino A., Patetta A., Ansaldi M., Porporato M. (2013) Toxicity of neonicotinoid insecticides on different honey bee genotypes. Bulletin of Insectology 66(1): 119-126.

Marletto F., Patetta A., Manino A. (2003) Laboratory assessment of pesticide toxicity to bumblebees. Bulletin of Insectology 56(1): 155-158.

Mayer D. F., Johansen C. A., Baird C. R. (1999) How to reduce bee poisoning from pesticides. Pacific Northwest Extension Publication PNW 518. Washington, Oregon, Idaho. 15 pp.

Mullin C. A., Frazier M., Frazier J. L., Ashcraft S., Simonds R., vanEngelsdorp D., Pettis J. S. (2010) High levels of miticides and agrochemicals in North American apiaries: Implications for honey bee health. PLoS One 5(3): e9754. DOl: 10.1371/journal.pone.0009754

OECD (1998) Gaudiness for the testing of chemical No. 213: Honeybees, Acute Oral Toxicity Test. Section 2. Effect on biotic systems. OECD. Paris. DOl: $10.1787 / 20745761$

OEPP/EPPO (2010a) EPPO Standards PP1/170 (4). Efficacy evaluation of plant protection products, Sideeffects on honeybees. Bulletin OEPP/EPPO Bulletin 40: 313-319.

OEPP/EPPO (2010b) EPPO Standards PP3/10 (3). Environmental risk assessment for plant protection products. Chapter 10: honeybees. Bulletin OEPP/EPPO Bulletin 40: 323-331.

Riedl H., Johansen E., Brewer L. J., Barbour J. (2006) How to reduce bee poisoning from pesticides. Pacific Northwest Extension Publication PNW 591. Oregon State University, University of Idaho, Washington State University. $28 \mathrm{pp}$.
Robertson J. L., Preisler H. K. (1992) Pesticide Bioassays with Arthropods. CRC Press. Boca Raton, FL, USA. 199 pp.

Sanford M. T (2009) Protecting honey bees from pesticides. University of Florida, IFAS Extention. 21 pp.

Sattelle D. B., Yamamoto D. (1988) Molecular targets of pyrethroid insecticides. Advances in Insect Physiology 20: 147-213.

Schricker B., Stephen W. P. (1970) The effect of sublethal doses of parathion on honeybee behaviour. I. Oral administration and the communication dance. Journal of Apicultural Research 9: 141-153.

Skerl M. S., Bolta S. V., Cesnik H. B., Gregorc A. (2009) Residues of pesticides in honeybee (Apis mellifera carnica) bee bread and in pollen loads from treated apple orchards. Bulletin of Environmental Contamination and Toxicology 83(3): 374-377.

Soderlund D. M., Bloomquist J. R. (1 989) Neurotoxic actions of pyrethroid insecticides. Annual Review of Entomology 34: 77-96.

Stevenson J. H. (1978) The acute toxicity of unformolated pesticides to worker honey bees (Apis mellifera L.). Journal of Plant Pathology 27(1): 38-40.

Tasei J. N., Carre S., Bosio P. G., Debray P., Hariot J. (1987) Effects of the pyrethroid insecticide, WL85871 and phosalone on adults and progeny of the leaf-cutting bee Megachile rotundata F, pollinator of lucerne. Journal of Pesticide Science 21(2): 119-128.

Tesoriero D., Maccagnani B., Santi F., Celli G. (2003) Toxicity of three pesticides on larval instars of Osmia cornuta: preliminary results. Bulletin of Insectology 56(1): 169-171.

Thompson H. M. (2003) Behavioural effects of pesticides in bees - their potential for use in risk assessment. Ecotoxicology 12: 317-330.

Thompson H. M. (2012) Interaction between pesticides and other factors in effects on bees. European Food Safety Authority Supporting Publications EN-340. 204 pp. Available at: http://fera.co.uk/ccss/documents/efsalnteractionOfFactorslnBees.pdf

Vandame R., Meled M., Colin M. E., Belzunces L. P. (1995) Alteration of the homing-flight in the honey bee Apis mellifera $L$. Exposed to sublethal dose of deltamethrin. 
Environmental Toxicology and Chemistry 14: 855-860.

Wu J. Y., Anelli C. M., Sheppard W. S. (201 1) Sub-lethal effects of pesticide residues in brood comb on worker honey bee (Apis mellifera) development and longevity. PLoS ONE 6(2): e14720. DOl: 10.1371/journal.pone.0014720
Yousef M. I. (2010) Vitamin E modulates reproductive toxicity of pyrethroid lambda-cyhalothrin in male rabbits. Food and Chemical Toxicology 48: $1152-1159$.

Zhang $H_{\text {., }}$ Wang H., ji Y. L., Zhang Y., Y U T., Ning H., Zhang C., Zhao X. F., Wang Q., Liu P., Xu D. X. (2010) Maternal fenvalerate exposure during pregnancy persistently impairs testicular development and spermatogenesis in male offspring. Food and Chemical Toxicology 48: 1160 1169. 